\title{
En tragedie i tre akter FRAMVEKSTEN AV DEN ISLAMSKE STATEN
}

\begin{abstract}
Organisasjonen som i dag kaller seg Den islamske staten, og dens forgjengere, har vokst fram som en konsekvens av konflikter som i utgangspunktet oppsto uavhengig av dem - først og fremst et militært og politisk sammenbrudd i Iraks sunniarabiske områder og det nordlige Syria.
\end{abstract}

Av Truls Hallberg Tønnessen, forsker ved Forsvarets Forskningsinstitutt.

ETTER AT GRUPPA SOM FOR TIDA KALLER SEG DEN islamske staten (al-dawla al-islamiyya) tok kontroll over store områder i Irak og Syria og erklærte opprettelsen av et nytt kalifat, har den fått svært mye internasjonal oppmerksomhet. ${ }^{1}$

Dette er også en oppmerksomhet gruppa i sterk grad har bidratt til selv ved å legge ut groteske filmer og bilder på nett som blant annet viser drap på religiøse minoriteter, sjiamuslimske soldater og halshugging av vestlige journalister. ${ }^{2}$ Det faktum at mange vestlige fremmedkrigere, norske inkludert, har sluttet seg til gruppa og figurerer i propagandamaterialet, har på ingen måte bidratt til å redusere oppmerksomheten.

Samtidig er det viktig å ikke stirre seg blind på Den islamske statens forseggjorte propagandakampanje og la denne oppmerksomheten skygge for en bredere forståelse av hva som kan forklare gruppas framvekst og hvilken kontekst den har oppstått i. Til tross for at gruppa tilsynelatende omtrent over natten ble en av de fremste internasjonale sikkerhetstruslene, er dette en gruppe med røtter som strekker seg i hvert fall ti år tilbake i tid.
For å forstå hvordan denne organisasjonen så raskt var i stand til å ta kontroll over et stort landområde i Irak og Syria, er det nødvendig å se litt på dens historikk og ikke minst hvordan den negative utviklingen i Irak og Syria de siste årene bidrar til å forklare dens framvekst. ${ }^{3} \mathrm{Et}$ hovedargument i denne artikkelen er at Den islamske staten og dens forgjengere primært må sees som et symptom på underliggende og mer grunnleggende konflikter som eksisterte uavhengig av gruppa. Organisasjonen har dessverre hatt en unik evne til å sette sitt preg på disse konfliktene som erfarne konfliktentreprenører og ved å stjele mye av oppmerksomheten fra de egentlige drivkreftene bak konfliktene som gruppa henter sin styrke og næring fra.

Første akt: Invasjonen av Irak i 2003 og etableringen av al-QQa'ida i Irak.

Opphavet til Den islamske staten (Is) kan spores ti år tilbake $\mathrm{i}$ tid til den amerikanskledete invasjonen av Irak i mars 2003 og det påfølgende fallet til den irakiske diktatoren Saddam Hussein og hans Baath-regime. I praksis førte også invasjonen og Saddams fall 


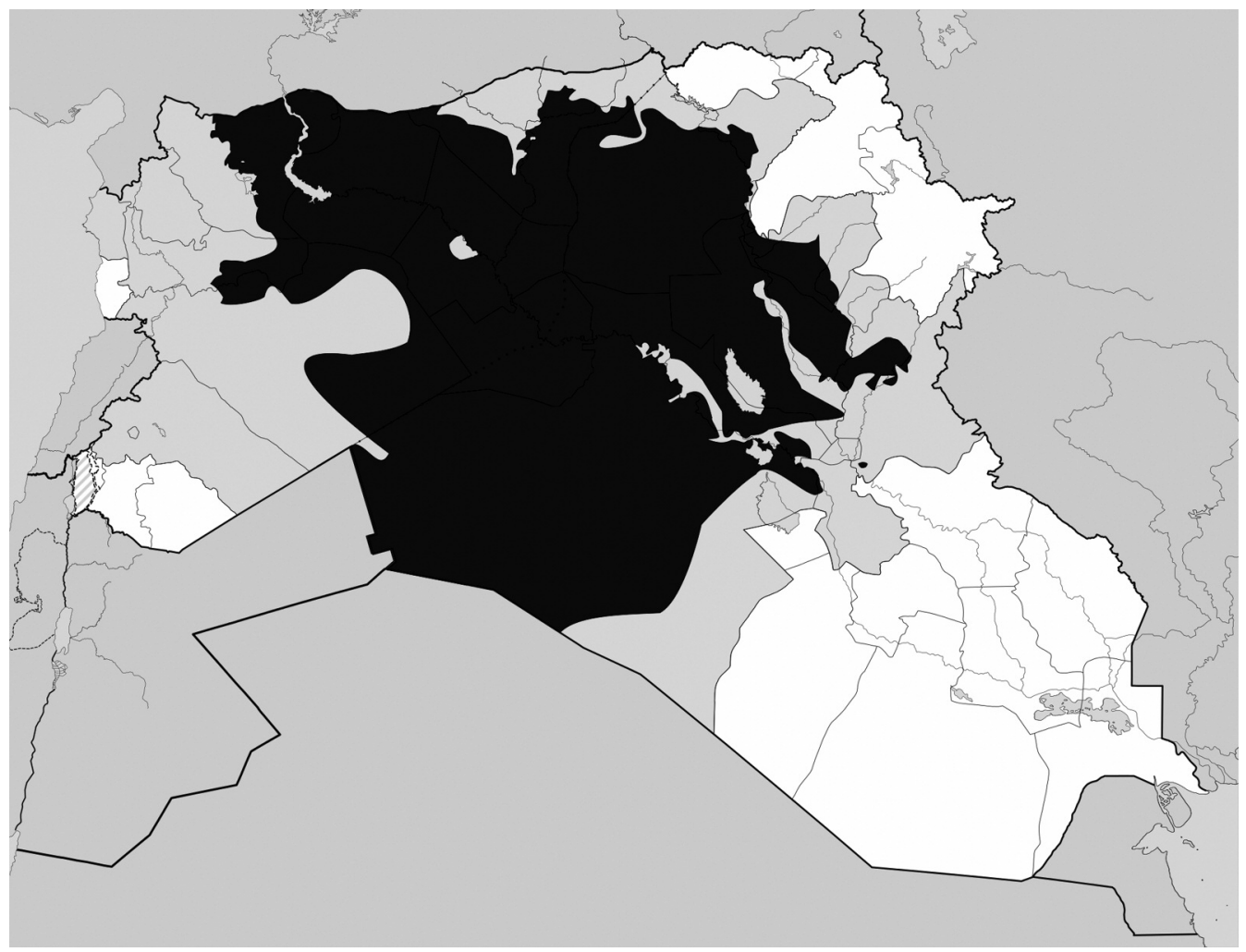

Områdene som kontrolleres av Den islamske staten.

til en maktforskyvning fra den sunni-arabiske minoriteten, som hadde dominert i Irak helt siden den moderne irakiske staten ble etablert etter første verdenskrig, og over til den sjiamuslimske majoriteten. ${ }^{4}$ Denne historiske omveltningen er et svært viktig bakteppe for det som i dag skjer i Irak.

Denne maktforskyvningen foregikk hovedsakelig på to måter. Det ene var den prosessen som har blitt omtalt som «de-baathifisering», og som i praksis gikk ut på at den amerikanske okkupasjonsmakten og deres irakiske allierte rev ned de gamle statsbærende institusjonene for å bygge opp en ny irakisk stat som ikke var assosiert med det forhatte Baath-regimet. Den irakiske hæren ble oppløst, noe som førte til at et sted mellom 400 ooo-800 ooo profesjonelle soldater og offiserer både mistet sin inntekt, sin posisjon i samfunnet og ikke minst sin evne til å forsørge familien. Som en del av debaathifiseringen mistet også mellom 50 ooo100 ooo tidligere offentlig ansatte sine stillinger på grunn av deres medlemskap i Baathpartiet.5 Dette rammet særlig den sunniarabiske minoriteten, ettersom de var overrepresentert i det gamle Baath-partiet. Et annet problem var at de som ble satt av usa til å gjennomføre denne opprenskingen var ledende sjiamuslimske eksilpolitikere som hadde samarbeidet med USA i opptakten til invasjonen og som hadde vært i opposisjon til Baath-partiet i årtier. Lederen var den kontroversielle Ahmad Chalabi, som hadde nære bånd til den neokonservative fløyen i det republikanske partiet i usA, og nestlederen var en da relativt ukjent opposisjonell fra det 


\section{TRULS HALLBERG TØNNESSEN}

shiamuslimske religiøse partiet al-Dawa, Nuri al-Maliki, senere Iraks statsminister fra 2006 til 2014. Nå var det disse og andre tidligere eksilbaserte opposisjonspolitikere som satt med makten til å bestemme hvem som skulle få tilbake jobbene sine og hvem som skulle bli ekskludert, og de brukte denne makten til å ekskludere sunni-arabiske rivaler. ${ }^{6}$ Fra sunniarabisk ståsted framsto dermed denne prosessen som en systematisk ekskludering av den sunni-arabiske minoriteten gjennomført av de amerikanske okkupasjonsstyrkene og deres sjiamuslimske og kurdiske allierte.?

Det bør også nevnes at den irakiske staten mer eller mindre hadde råtnet på rot allerede i forkant av invasjonen. Irak var sterkt preget av de økonomiske konsekvensene etter Iran-Irak krigen (1980-1988), Gulfkrigen i 1990-1991 og det økonomiske sanksjonsregimet pålagt Irak etter Iraks invasjon av Kuwait i 1990. Dette bidro til at den irakiske staten utover på 1990tallet ble mer og mer opptatt av å sikre sin egen overlevelse framfor å administrere en stat. ${ }^{8}$ Den offisielle staten ble i stedet erstattet av det Charles Tripp har kalt en «skyggestat» hvor det var nettverk tett knyttet til Saddam Hussein som garanterte regimets overlevelse. ${ }^{9}$

Da de nye makthaverne i Irak oppløste den gamle hæren og i praksis demonterte det som var igjen av den gamle statsbærende orden, oppsto det også et maktvakuum de amerikanske soldatene ikke var i stand til å fylle. Dette førte til en fragmentering og desentralisering av den politiske autoriteten i Irak hvor mange irakere i stedet søkte til sekterisk eller etnisk-baserte militser for sikkerhet. Disse militsene var i stor grad knyttet til de organisasjonene som hadde vært i opposisjon til det gamle regimet, slik som kurdiske peshmerga, knyttet til de sentrale kurdiske partiene Kurdistans demokratiske parti og Kurdistans patriotiske union, og Badr-militsen (Faylaq
Badr) knyttet til den iranskstøttede sjiaislamske organisasjonen som fram til 2003 kalte seg for Det øverste rådet for den islamske revolusjonen i Irak (SCIRI). I tillegg fikk også Mahdi-militsen (Jaysh al-Mahdi), knyttet til den unge sjiamuslimske predikanten Muqtada al-Sadr fra den innflytelsesrike sjiamuslimske Sadr-familien, raskt mye innflytelse. Dette var organisasjoner som i årtier hadde vært i konflikt med det gamle regimet og som var i stand til raskt å fylle det maktvakuumet som oppsto etter regimets fall. Sunni-araberne hadde på sin side få organisasjoner utover et Baath-parti som nå lå i ruiner, og mange sunni-arabere organiserte seg i stedet i væpnede opprørsgrupper mot okkupasjonsmakten og deres irakiske allierte. ${ }^{10}$

Både blant de sunni-arabiske opprørerne og blant de sjiamuslimske militsene spilte religion en sentral rolle. En viktig grunn til dette var at islam generelt fikk økt innflytelse i det irakiske samfunnet under sanksjonstiden i tiåret før invasjonen av Irak, både som en direkte effekt av den vanskelige situasjonen for sivilbefolkningen under sanksjonsregimet og som en følge av at Saddam Hussein i mye større grad enn før brukte islam for å legitimere sitt styre. ${ }^{11}$ Da USA invaderte Irak i 2003 og fjernet det gjenværende irakiske statsapparatet, var religiøse nettverk sentrert rundt enkelte moskeer, religiøse ledere eller religiøse partier blant de få strukturene som fortsatt var intakte.

Sunni-araberne følte seg også politisk ekskludert ettersom de ble marginalisert i det som ble kalt The Iraqi Coverning Council og som fungerte som en slags provisorisk irakisk regjering under amerikansk overherredømme. ${ }^{12} \mathrm{De}$ amerikanske administratorene bestemte at dette rådet skulle basere seg på Iraks etniske og sekteriske fordeling, noe som medførte at det var sjiamuslimsk flertall i rådet mens sunni- 
araberne og kurderne fikk 20 prosent av setene hver. Resten ble fordelt på øvrige minoriteter. I praksis ble rådet fylt opp av tidligere eksilpolitikere som dermed fikk stor påvirkning på den videre politiske utviklingen i Irak. Som en rekke irakforskere har påpekt, innførte den amerikanske administrasjonen med dette sekteriske identiteter som det organiserende prinsippet for det politiske livet i Irak. ${ }^{13}$

Hvor viktig sekteriske og etniske identiteter var i politikken ble særlig tydelig ved parlamentsvalget og lokalvalget i Irak i januar 2005. Mens sunni-araberne i stor grad boikottet valgene, stemte kurderne på de overnevnte kurdiske partiene og sjiamuslimene på de overnevnte sjiamuslimske partiene. Disse partiene, inkludert deres militser, fikk dermed overproporsjonal politisk innflytelse både på

\section{Den irakiske staten hadde mer eller mindre råtnet på rot allerede i forkant av invasjonen i 2003.}

nasjonalt og lokalt plan. ${ }^{14}$ For eksempel fikk SCIRI kontroll over innenriksdepartementet under ledelse av innenriksminister Bayan Jabar Solagh. Han utnyttet sin stilling til å la sciris Badr-milits infiltrere både politi og de nye irakiske sikkerhetsstyrkene, og det er flere rapporter som antyder at innenriksministeriet under Solaghs ledelse var involvert i tortur og drap på sunni-arabere. ${ }^{15}$

Det var i denne konteksten at Is' forløper alQa'ida i Irak ble grunnlagt av den jordanske Afghanistan-veteranen Abu Mus'ab al-Zarqawi som hadde etablert seg i leirene til den kurdiske islamistgruppa Ansar al-Islam i forkant av invasjonen av Irak. Cruppa besto i utgangspunktet av noen få jordanske og syriske veteraner fra Zarqawis treningsleir i Herat i Af- ghanistan, men gruppas størrelse økte gradvis ved at de tiltrakk seg noen av fremmedkrigerne som kom til Irak for å slåss mot okkupasjonen. De greide også å tiltrekke seg en del irakere, da særlig irakere som hadde tilhørt en salafibevegelse som hadde vokst fram i Irak i tiåret før invasjonen. ${ }^{16}$

En sentral del av Zarqawis strategi i Irak var å utnytte den sunni-arabiske misnøyen med deres stilling i det nye Irak og de amerikanske soldatenes behandling av lokalbefolkningen, særlig symbolisert gjennom de amerikanske fangevokternes bilde fra Abu Chraib-fengselet. Zarqawi og hans gruppe forverret ytterliggere forholdet mellom sunniaraberne og sjiamuslimene gjennom en storstilt selvmordsangrepskampanje mot sjiamuslimene. ${ }^{17}$

I april 2004 erklærte gruppa sin eksistens i Irak under navnet Tawhid wa'l-Jihad, og fikk raskt stor internasjonal oppmerksomhet da de i mai 2004 la ut en film på internett som viste halshuggingen av amerikaneren Nicholas Berg. ${ }^{18}$ Det var Zarqawi selv som sto for henrettelsen. Crunnet denne filmen og flere andre tilsvarende halshuggingsvideoer fra 2004 fikk han tilnavnet "slakternes sjeik» (shaykh aldhabbahin). Gjennom slike handlinger fikk Zarqawi og hans gruppe svært mye internasjonal oppmerksomhet til tross for at gruppa kun utgjorde en liten del av en mye bredere sunni-arabisk opprørsbevegelse.

I oktober 2004 byttet Tawhid wa'l-Jihad navn til Tanzim al-Oa'ida fi'Bilad al-Rafidayn, som regel referert til som al-Oa'ida i Irak (AOI) og ble inkludert i al-Oa'ida-nettverket som den offisielle representanten for nettverket i Irak. ${ }^{19}$ Selv om dette i teorien innebar at AQI var underlagt al-Qa'ida sentralt og måtte adlyde ordre fra lederskapet, var det ikke alltid slik i praksis. Sentrale ledere i al-Qa'ida, inkludert dagens leder Ayman al-Zawahiri, kritiserte Zarqawi og AQI for deres drap på irakiske sivile og for 
generelt å opptre lite pragmatisk overfor potensielle lokale allierte. ${ }^{20}$ Til tross for visse uenigheter ble AQI styrket gjennom inkluderingen i al-Qa'ida nettverket ved at de fikk tilgang på finansiell støtte fra privatpersoner i Culfen og et økende antall fremmedkrigere som sluttet seg til gruppa. ${ }^{21}$

Gjennom 2004 og 2005 bygde AQI opp en slagkraftig militær organisasjon som gradvis $ø$ kte sin innflytelse i det sunni-arabiske området, særlig i Anbar-provinsen og i noe mindre grad i Ninawah-provinsen lenger nord. Disse to provinsene grenser til Syria og AQI etablerte flere mottakssentre langs grensa for fremmedkrigerne som kom inn til Irak via Syria. ${ }^{22}$ Når man i dag spør seg hvordan is kan være i stand til å ta kontroll over store områder i Irak og i Syria, skal man ikke glemme at Is' forløper etablerte en av al-Qa'ida-nettverkets sterkeste lokale avdelinger og $i$ en periode var en av de sterkeste aktørene i Anbar-provinsen, til tross for at det var utstasjonert over 100 ooo militært overlegne amerikanske soldater der med et uttalt mål om å bekjempe al-Qa'ida. ${ }^{23}$ Den viktigste grunnen til at det var vanskelig for de amerikanske styrkene å bekjempe AQI i Anbarprovinsen var at lokalbefolkningen i området i liten grad var villig til å identifisere medlemmer av AQI til de amerikanske styrkene. Lokalbefolkningen fryktet brutale represalier fra AQI eller så på AQI som en nyttig alliert i kampen mot okkupasjonsstyrkene og mot de sjiadominerte sikkerhetsstyrkene. Uten samarbeid med lokalbefolkningen var det nesten umulig å skille mellom sivile, lokale opprørere og medlemmer av al-Qa'ida. ${ }^{24}$

På grunn av AQIs brutale interaksjon med lokalbefolkningen og praktisering av en ytterliggående versjon av islam, har AQI og dens etterfølgere imidlertid tradisjonelt hatt problemer med å omsette sine militære seire til politiske serie. Hver gang gruppa har blitt dominerende $i$ et område har den hatt en tendens til å gjøre seg til uvenner med lokalbefolkningen og tidligere alliansepartnere. I 2005 var det for eksempel et gryende stammeopprør mot AQI i Anbar ettersom gruppa både utfordret stammenes maktposisjon og fordi den blandet seg inn i smuglervirksomheten mellom Irak og Syria som tradisjonelt hadde vært en viktig inntekt for en del stammeledere i grenseområdene. ${ }^{25}$ Uten hjelp og beskyttelse fra de amerikanske styrkene var det imidlertid vanskelig for stammene å bekjempe Aol som i tillegg avskrekket enhver motstand ved å brutalt myrde lederne av opprør mot dem. Samtidig bidro dette til å presse fram en taktisk allianse mellom en del stammeledere og de amerikanske styrkene som innså at de hadde en felles interesse av å bekjempe Aỡ. Denne ut-

\section{Al-Qai'da i Irak har hatt en tendens til å gjøre seg til uvenner med lokalbefolkningen og tidligere alliansepartnere.}

viklingen ble forsterket av at innflytelsesrike sunni-arabere gradvis innså at det å delta i politikken og å forhandle med amerikanske styrker kunne styrke deres posisjon vis-a-vis et regime og sikkerhetsstyrker som mer og mer ble dominert av sjiamuslimer. ${ }^{26}$ Både Aôs offisielle kommunikeer og deres interne dokumenter indikerer at det var svært viktig for dem å forpurre denne utviklingen ved å målrettet angripe sunni-arabere som ville delta i den politiske prosessen og samarbeidet med de amerikanske styrkene. ${ }^{27}$ Dette bidro til å trekke AQI inn $i$ en negativ spiral hvor gruppa i økende grad prioriterte å angripe sunni-arabere som gikk imot dem. ${ }^{28}$

Delvis som en reaksjon på det gryende 
stammeopprøret og delvis som et forsøk på å formalisere sin økende innflytelse i Anbarprovinsen, erklærte AQI i oktober 2006 at de sammen med flere andre, mindre sunni-arabiske opprørsgrupper hadde opprettet en islamsk stat i Irak (al-dawla al-Islamiyya fi'l-'Iraq) under ledelse av Abu Omar al-Baghdadi med hovedsete i Anbars provinshovedstad, Ramadi. Denne nye staten (forkortet til IsI) skulle dekke de sunni-arabiske delene av Irak. Til forskjell fra den islamske staten som ble opprettet i 2014 hadde de i 2006 kun kontroll i spredte områder i denne staten, hovedsakelig i Anbar.

Etter opprettelsen forlangte de at alle sunniarabere i området, stammeledere og opprørsledere inkludert, skulle sverge ed til den nye staten og anerkjenne autoriteten til Baghdadi. Dette førte til at flere opprørere i stedet for å bekjempe amerikanske soldater begynte å slåss mot Isı. Grunnet en økning i antall amerikanske styrker i Irak og en økt villighet til å samarbeide med opprørerne mot IsI, inngikk en del av stammelederne og opprørerne et midlertidig taktisk samarbeid med amerikanerne i kampen mot deres felles fiende, ISI. ${ }^{29}$ En annen viktig faktor som gjorde dette samarbeidet mulig var at sunni-araberne fikk løfter om at de i større grad skulle bli inkludert i sikkerhetsstyrkene og få økt politisk innflytelse. Kombinasjonen av den overlegne amerikanske militærkapasiteten og stammenes lokalkunnskap viste seg svært effektivt og ISI mistet fort fotfeste i Anbar i løpet av 2007. I 2008 lå IsI med brukket rygg, og både irakiske og amerikanske myndigheter erklærte at gruppa var knust. ${ }^{30}$

Andre akt: Framveksten av Den islamske staten i Irak og Syria.

Det skulle imidlertid vise seg å være for tidlig å erklære Den islamske staten i Irak for død og begravet. Isi styrket seg gradvis, og i 2009 og 2010 gjennomførte gruppa flere store og koordinerte terrorangrep rettet mot det irakiske regimet, mot sjiamuslimer og minoriteter som de kristne. ${ }^{31}$ Men til tross for at de var i stand til å gjennomføre store terrorangrep, var isi fortsatt langt fra sin tidligere styrke og ute av stand til å reetablere territoriell kontroll.

Årene 2008 og 2009 var små lysglimt i et ellers ganske så mørkt tiår i Irak. Isı lå med brukket rygg, voldsnivået for øvrig sank dramatisk fra toppåret i 2007, sunni-araberne sluttet i mye større grad opp om den politiske prosessen og provinsvalget i 2009 ble sett på som en seier for de nasjonalistiske, samlende kreftene på bekostning av de mer splittende og sekteriske kreftene. ${ }^{32}$ Og det er kanskje her man finner den virkelige tragedien - at denne positive utviklingen ikke førte fram og at Irak i dag i stedet befinner seg i kanskje den verste krisen i landets moderne historie.

For å finne svar på hvorfor det gikk så galt, holder det ikke kun å skylde på al-Qa'ida, som de irakiske myndighetene har hatt en tendens til å gjøre. Irak sliter med en rekke grunnleggende utfordringer som myndighetene ikke har greid å løse og dette har bidratt til å gi alQa'ida en mulighet til å utnytte en økende misnøye med regimet. Irak er for eksempel rangert som et av verdens mest korrupte land, noe som har svekket myndighetenes evne til å tilby tjenester til en befolkning som har mistet tillitten til myndighetene og til politikerne. ${ }^{33}$ Misnøyen med regimet førte også til at det i første halvdel av 2011 vokste fram en irakisk variant av den arabiske våren med demonstrasjoner over hele Irak rettet særlig mot den utstrakte korrupsjonen og regimets manglende evne til å tilby grunnleggende tjenester. ${ }^{34}$ Disse demonstrasjonene bidro til at regimet beveget seg i en mer autoritær retning, noe som ytterligere bidro til å svekke befolkningens oppslutning om regimet, særlig blant den sunni-arabiske 
TRULS HALLBERG TØNNESSEN

minoriteten som ble ekstra hardt rammet av denne utviklingen. 35

I tillegg har konsekvensene av konflikten for sivilbefolkningen i isıs kjerneområde vært katastrofale. En rapport fra 2008 fant for eksempel at i 47 prosent av husholdningene i Anbar-provinsen hadde et husholdningsmedlem blitt drept mellom 2006 og 2008, og en stor andel barn hadde vokst opp uten en far. ${ }^{36}$ Dette har skapt en generasjon som har vokst opp med ti års konflikt og dårlige framtidsutsikter, hvor mange overbevises av is' løfter om penger, lokal makt og innflytelse og mulighet for hevn mot de sjiamuslimske «undertrykkerne» på en måte som få andre

\section{$\infty$ \\ IS lover mulighet for hevn mot de sjia- muslimske «undertrykkerne» på en måte som få andre rivaliserende aktører tilbyr. $\infty$}

rivaliserende aktører tilbyr. ${ }^{37} \mathrm{Både} \mathrm{AQI} \mathrm{og} \mathrm{Is} \mathrm{har}$ tradisjonelt rekruttert lokalt primært blant sunni-arabere som var i en ekstra sårbar situasjon, som unge og arbeidsledige fra fattige lag av befolkningen som har mistet familiemedlemmer.

På mange måter kan man si at mens AQI $\mathrm{i}$ stor grad var en direkte konsekvens av den amerikanske invasjonen av Irak i 2003, er dagens organisasjon i mye større grad en indirekte konsekvens av ti år med konflikt og kaos i kjølvannet av den amerikanske invasjonen, inkludert en opprivende borgerkrig mellom sjiamuslimer og sunni-arabere. AQI ble grunnlagt av fremmedkrigere som kom til Irak for å slåss mot den amerikanske okkupasjonsmakten og flere av de historiske grunnleggerne var Afghanistan-veteraner med personlige bånd til al-Qa'idas ledelse. ${ }^{39}$ Over tid ble AQI i økende grad dominert av irakere som aldri hadde vært i Afghanistan eller som noen gang har møtt den sentrale al-Oa'ida-ledelsen. Ifølge gruppa selv opphørte også AQ formelt å eksistere da den ble en del av den islamske staten i 2006. Enkelte av de sentrale medlemmene i ISI hadde også bakgrunn fra andre grupper enn AOI. Dagens Is-leder og selverklærte kalif Abu Bakr al-Baghdadi skal for eksempel angivelig ikke ha tilhørt AQI, men en av de andre gruppene som var med på å opprette Den islamske staten i 2006.40

Ettersom de originale AQI-medlemmene over tid ble drept, arrestert eller forlot Irak, er gruppa i dag i stor grad dominert av irakere som ble radikalisert som en følge av de historiske omveltningene og de blodige konfliktene Irak opplevde etter Saddam-regimets fall. For eksempel er det indikasjoner på at flere av topplederne for is er tidligere offiserer fra den gamle hæren til Saddam Hussein. ${ }^{41}$ En annet fellestrekk er at mange av dagens ledere har vært fanger i amerikanskdrevne fengsler, hvor de kan ha blitt radikalisert som følge av negative opplevelser og vervet til AQI som drev aktiv rekruttering inne i fengslene og blant tidligere innsatte. ${ }^{42}$

Den viktigste grunnen til at IsI var i stand til å komme tilbake er imidlertid to ulike konflikter som oppsto uavhengig av IsI, men som begge bidro til å skape en situasjon som var gunstig for Isı; en politisk krise i Irak og en svært voldelig konflikt i nabolandet Syria.

I Irak var det en tiltagende politisk krise etter valget i 2010, da det ble dødt løp mellom koalisjonen til statsminister Maliki og koalisjonen til Ayad al-Allawi, som også inkluderte sentrale sunni-arabiske politikere. Denne konflikten eskalerte særlig etter at de siste amerikanske styrkene trakk seg ut i desember 2011, og allerede dagen etter utstedte det sjiadominerte regimet til statsminister Maliki 


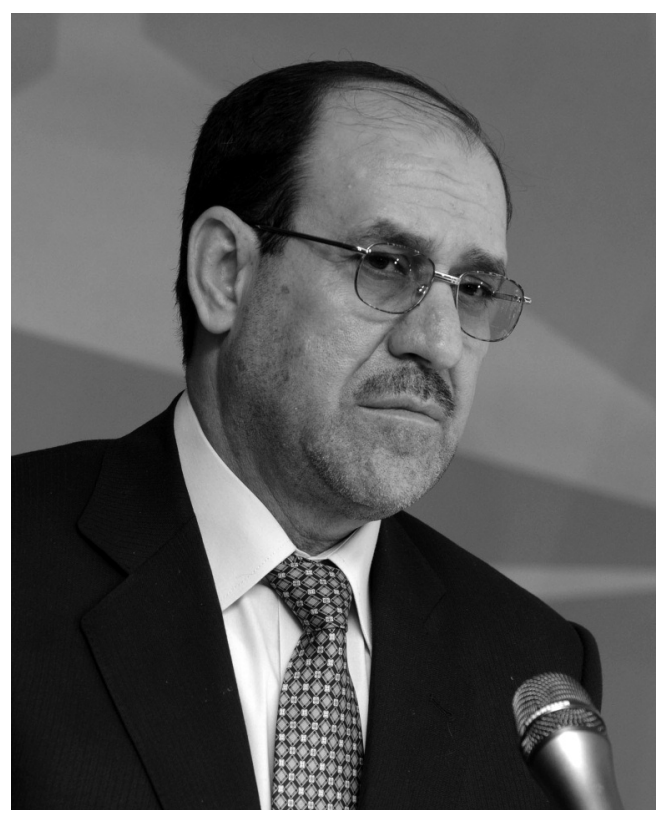

Iraks tidligere statsminister Nouri al-Maliki fjernet ofte sunniarabiske politiske rivaler ved å anklage dem for voldshandlinger

arrestordre på Iraks sunni-arabiske visepresident Tariq al-Hashimi for angivelig tilknytning til terrorisme. Hashimi flyktet til irakisk Kurdistan og ble i 2012 dømt til døden in absentia. Et viktig bakteppe for denne arrestordren og andre inngripener mot sunni-arabiske politikere var at flere sunni-arabiske provinser i forkant hadde ytret ønske om større selvstyre og uavhengighet fra sentralmyndighetene i Bagdad. 43

Dette var langt fra den eneste gangen Maliki fjernet sunni-arabiske politiske rivaler ved å anklage dem for å være knyttet til voldshandlinger i Irak eller å ha for tette bånd til det gamle Baath-partiet. Konflikten mellom sunni-arabiske og sjiamuslimske aktører ble drevet fram av sunni-arabiske krav om økt innflytelse og regimets manglende vilje til å imøtekomme disse kravene. Særlig i kjølvannet av arrestordren på den svært populære sunni-arabiske finansministeren Rafi al-'Issawi i desember 2012 oppsto det en bred og mangefasettert protestbevegelse rettet mot regimet, særlig i Anbar-provinsen. Flere sunniarabiske politikere, stammeledere og mer militante grupper, slik som Naqshbandihæren med koblinger til det gamle Baathpartiet, var involvert og delvis konkurrerte om å være ledende i denne protestbevegelsen. ${ }^{44} \mathrm{Til}$ tross for få indikasjoner på at Isı var en viktig drivkraft bak denne bevegelsen, og at få av aktørene støttet deres ideologi, anklaget regimet Isı for å stå bak. Bevegelsen var også i utgangspunktet relativt fredelig, og besto i hovedsak av demonstrasjoner og etableringen av ulike protestleire. 45

Denne sunni-arabiske protestbevegelsen beveget seg imidlertid i mer voldelig retning etter at spesialstyrker direkte underlagt Maliki i april 2013 gikk til aksjon mot en protestleir i Hawija i Kirkuk, hvor rundt 40-50 demonstranter ble drept. Denne hendelsen førte til en kraftig eskalering av voldsnivået i Irak. Ifølge FN gikk tallet på drepte sivile i Irak opp fra 229 i mars til 595 i april og 963 i mai, og 2013 ble det blodigste året i Irak siden 2008.46 Den eskalerende konflikten og at regimet hadde problemer med å opprettholde kontroll i de sunni-arabiske områdene, isis kjerneområder, var en viktig foranledning til de dramatiske hendelsene i 2014.

IsI hentet også økonomisk og militær styrke fra den tragiske konflikten i nabolandet Syria. ${ }^{47}$ Dette var en konflikt som på ingen måte handlet om al-Qحa'ida i utgangspunktet, men hovedsakelig en konflikt mellom en sunni-arabisk majoritet og et regime dominert av allawitter, en avart av sjiaislam. Dermed foregikk konflikten i Syria og i Irak grovt sett langs de samme aksene; sunni-arabere mot sjiamuslimer og den svært blodige konflikten i Syria førte til mobilisering på sekterisk grunnlag ikke bare i Syria og Irak, men også i Libanon. Isı blandet seg etter hvert inn i denne 
TRULS HALLBERG TøNNESSEN

orientalske heksegryta, først ved, ifølge deres egen framstilling, å etablere en slags syrisk avlegger under navnet Nusra-fronten (Jabhat alNusra) og i april 2013, altså omtrent samtidig med at voldsnivået eskalerte i Irak, erklærte gruppa offisielt at de var tilstede i Syria og byttet navn til Den islamske staten i Irak og i stor-Syria (al-dawla al-Islamiyya fi'l-'Iraq wal-sham). Isıs forlangte også at Nusra-fronten skulle bli integrert i denne nye organisasjonen, men Nusra motsatte seg dette og sverget i stedet ed til al-Q_aidas øverste leder, Ayman al-Zawahiri, og ble med det al-Qaidas offisielle representant i Syria. ${ }^{48}$ Etter dette oppsto det også en disputt mellom Nusra-fronten og isis om hvem som egentlig hadde tatt initiativ til å blande seg inn i konflikten i Syria og opprette Nusra. ${ }^{49}$

Isis utnyttet det maktvakuumet som oppsto da syriske styrker trakk seg ut av Nord-Syria og overlot områdene til en svært fragmentert syrisk opprørsbevegelse som kjempet mot regimet til Bashar al-Assad. De tok raskt kontroll over strategiske deler av opprørskontrollerte områder, som grenseoverganger og oljefelt. ${ }^{50}$ Gjennom sine erobringer skaffet de seg også tilgang på våpen de tok fra andre opprørere eller som regimet hadde latt være igjen. En stor andel av det rekordstore antallet fremmedkrigere som hadde kommet til Syria for å slåss mot det syriske regimet, gikk nå over til Isıs. ${ }^{51}$ Særlig fra januar 2014 møtte isis imidlertid mer motstand i Syria da en bred allianse av syriske opprørsgrupper, med støtte fra flere Culfland, var i stand til å fravriste isis midlertidig territoriell kontroll, særlig i Vest-Syria. ${ }^{52}$

Tredje akt: Opprettelsen av Den islamske staten. Omtrent samtidig bidro utviklingen i Irak til å gi isis en mulighet for å kompensere for sin svekkede stilling i Syria ved å øke sin aktivitet og innflytelse i Irak. Sent i desember 2013 arresterte Maliki sentrale ledere for demonst- rasjonene i Ramadi, og anklaget dem for å være medlemmer av Isis. Protestleirene ble fjernet, og det ble erklært unntakstilstand i Ramadi. ${ }^{53}$

Isis benyttet det sikkerhetsmessige sammenbruddet i Anbar til å rykke inn i Ramadi og særlig i Fallujah og erklære at de hadde tatt over kontrollen her. Hvor mye kontroll isis faktisk hadde i Fallujah er usikkert, men regimet erklærte uansett at de ville angripe byen ettersom den nå var under kontroll av terrorister. Dette førte til en sunni-arabisk mobilisering i Fallujah og andre steder i Anbar mot regimets sjiadominerte sikkerhetsstyrker som hadde liten støtte i den sunni-arabiske Anbar-provinsen. ${ }^{54}$

Mange av de aktørene som hadde vært involvert i protestbevegelsen mot regimet organiserte seg i diverse stammeråd og militærråd med navn som General Military Council for Iraqi Revolutionaries (GMCIR) og Military Council of Iraqi Tribal Revolutionaries. Disse rådene organiserer hovedsakelig tidligere sunni-arabiske offiserer, tidligere opprørere, inkludert opprørere som tilbake i 2006-2007 kjempet mot al-Qaida i Irak og en rekke stammeledere. Det er tydelige koblinger mellom GMCIR og Naqshbandia-hæren ledet av Saddam Husseins gamle visepresident Izzat al-Douri, mens stammerådene i større grad ser ut til å være knyttet til de stammene som i 2006-2007 samarbeidet med usA mot alQaida.55 Ingen av disse delte IsIs' ideologi, men de ble bundet sammen i en felles kamp mot regimet. Ettersom flere i dagens Isis-lederskap har bakgrunn fra hæren til Saddam Hussein er det heller ikke utenkelig at det var personlige forbindelser mellom enkelte isis-ledere og andre opprørsledere.

Denne sunni-arabiske alliansen mot regimet, som delvis ble skapt som følge av beleiringen av Fallujah i januar, var også sentral 
da IsIs overtok store deler av Mosul i juni 2014, selv om det er noe uenighet om hvor viktig rolle de andre sunni-arabiske gruppene spilte i overtakelsen. ${ }^{56}$ Etter opprettelsen av Den islamske staten 29. juni har det imidlertid vært indikasjoner på sammenstøt mellom Isıs og andre sunni-arabiske grupperinger. ${ }^{57}$

Dette er også et trekk som har gått igjen i AQI/ISIs sin historie - de får noe støtte fra lokale samarbeidspartnere så lenge de er alliert mot en felles fiende, men kommer ofte i konflikt med sine tidligere allierte når de begynner å konkurrere om innflytelsen i området etter at den samlende fienden har trukket seg ut.

\section{Konklusjon}

Et hovedpoeng i denne artikkelen er at framveksten av organisasjonen som i dag kaller seg Den islamske staten og dens forgjengere hovedsakelig er et symptom på, og en konsekvens av, konflikter som i utgangspunktet oppsto uavhengig av AQI/Is. Det som har muliggjort Is' sterke posisjon i dag er et militært og politisk sammenbrudd i de sunniarabiske områdene i Irak og i Nord-Syria. Dette er også den befolkningsgruppa is rekrutterer fra og har vært kjerneområdet for gruppas aktivitet helt tilbake til oppstarten i 2003/2004. I Syria skyldes mye av gruppas styrke andre aktørers svakhet og fragmentering, i tillegg til at det syriske regimet inntil nylig lot IS holde på så lenge de angrep andre opprørere og oppfylte regimets propaganda om at det kun var regimet som kunne forhindre at Syria ble overtatt av religiøse ekstremister. I Irak har is fått styrke ved at de kunne operere i samarbeid med andre sunni-arabiske opprørere i en felles kamp mot det sjia-dominerte regimet.

Is er også en organisasjon som henter styrke i tider med høy grad av usikkerhet, kaos og konflikt. Ved å framstå som den sterkeste lokale aktøren i et ellers svært så fragmentert aktørbilde, som både kan tilby lokalbefolkningen enkelte goder og sikkerhet, og samtidig behandler de som ikke støtter dem på en svært brutal måte, får gruppa passiv støtte fra en del sunni-arabere som ellers ikke ville hatt noe til overs for den. Dette innebærer at det er vanskelig å bekjempe is uten også å adressere de mer grunnleggende konfliktene $i$ områdene is henter støtte og lokale allierte fra.

Samtidig har gruppa hatt en tendens til å støte fra seg lokale allierte ved å opptre brutalt og ved å insistere på at gruppa er en stat som alle andre opprørere må anerkjenne og underkaste seg. Dette var en av grunnene til at Is' forløper al-Oaida i Irak i 2007-2008 ble kraftig svekket. Is insisterer imidlertid nå på at de har lært av tidligere feil og forsøker å bygge opp et bedre forhold til lokalbefolkningen. Hva som skjer med is framover avhenger med andre ord både av hva som skjer med konfliktene is opererer innenfor og hvordan is forholder seg til eventuelle lokalt allierte. Fraværet av sikkerhet og stabilitet, og de enorme lidelsene lokalbefolkningen i Is' kjerneområder har gått igjennom, indikerer dessverre at is vil være en faktor å regne med i lang tid framover.

\section{$\bullet$}

1 Takk til Espen Berg-Knutsen, FFI og de to anonyme fagfellene for grundige og fruktbare tilbakemeldinger på artikkelen.

2 For mer om mediestrategien til al-Qaida i Irak se Tønnessen, Truls H: "Brutal medieoppmersomhet. AlQaida i Irak på nett”, i Babylon, vol. 10, nr 1, 2012.

3 Denne artikkelen baserer seg i stor grad på artikkelforfatterens doktoravhandling "al-Qaida in Iraq: The rise, the fall and the comeback," Universitetet i Oslo, innlevert 2014.

4 For mer om dette se for eksempel Dodge, Toby: "Iraq's Future: The Aftermath of Regime Change," i Adelphi Paper, nr 372, 2005.

5 Det har blitt anslått at rundt 1.6 millioner irakere mistet sin hovedinntekt som en følge av denne prosessen. Se "Iraq: Building a New Security Structure," International Crisis Croup, 23 December 2003, s.13. Se også Herring, Eric og Clen Rangwala: Iraq in Fragments - The Occupation and Its Legacy. London: Hurst, 2006, s.73, Haron Otterman: "IRAQ:Debaathification", Council on Foreign Relations, 7. april 2005 og “Loose Ends: Iraq's Security Forces between 


\section{TRULS HALLBERG TØNNESSEN}

U.S. Drawdown and Withdrawal," International Crisis Group, 26. oktober 2010.

6 Herring og Rangwala: Iraq in Fragments, s. 134.

7 Allawi, Ali A: The Occupation of Iraq-Winning the War, Losing the Peace. New Haven: Yale University Press, 2007, s.149, 152.

8 Ibid, s.115, 121.

9 Tripp, Charles: “After Saddam," i Survival, vol. 44, nr 4, 2002, s.22-37.

10 For mer om dette se særlig Dodge, Toby: "Iraq's Future: The Aftermath of Regime Change," Adelphi Paper, nr. 372, 2005 og Herring, Eric and Clen Rangwala, Iraq in Fragments - The Occupation and Its Legacy.

11 Haddad, Fanar: Sectarianism in Iraq: Antagonistic Visions of Unity, London: Hurst, 2011), 104-105, Luizard, Pierre Jean: "Islam as a Point of Reference for Political and Social Groups in Iraq" i International Review of the Red Cross, vol. 89, $\mathrm{nr}$ 868, 2007 og Baram, Amatzia: "From Militant Secularism to Islamism" HAPP Occasional Paper, Woodrow Wilson International Center for Scholars, oktober 2011.

12 Hashim, Ahmad: Insurgency and Counter-Insurgency in Iraq. Ithaca, New York: Cornell University Press, 2006, s.18, 75.

13 Haddad, Fanar: Sectarianism in Iraq: Antagonistic Visions of Unity. London: Hurst, 2011, s.148-151, Marr, Phebe: "Iraq's Identity Politics", i Iraq-Preventing a New Ceneration of Conflict, red. Markus E. Bouillon, David E. Malone \& Ben Roswell, 41-54. Boulder: Lynne Rienner Publishers, 2007, s.42 og "The Next Iraqi War? Sectarianism and Civil Conflict", International Crisis Group, 27. februar 2006.

14 "Iraq's Provincial Election: The Stakes," International Crisis Group, januar 2007, s.1-7 og Knights, Michael og Eamon McCarthy: "Provincial Politics in Iraq, Fragmentation or New Awakening," Policy Focus \#81, april 2008, The Washington Institute for Near East Policy.

15 "The Next Iraqi War? Sectarianism and Civil Conflict", International Crisis Group, 27. februar 2006, Cockburn, Patrick: The Occupation - War and Resistance in Iraq. London: Verso, 2007, s.193 og Rosen, Nir: "On the Ground in IraqThe Roots of Sectarian Violence," Boston Review, mars/april 2006.

16 Slik som for eksempel Umar Hadid, Abu Talha al-Mawsuli, Abu Maysarah al-Iraqi og Abu Azzam al-Iraqi.

17 Se særlig Hafez, Mohammed M: Suicide Bombers in Iraq-The Strategy and Ideology of Martyrdom. Washington D.C: United State Institute of Peace Press, 2007.

18 Abu Mus'ab al-Zarqawi, "Statement to Umma," (arabisk) datert 11. mai 2004, trykket i "The Electronic Book of alJama'at al-Tawhid wa'l-Jihad," publisert av Clobal Islamic Media Front, oktober 2004, lastet ned fra Shabakat alAkhbar al-'Alamiyya, bayanat.info/showthread. php?t=2200 29. august 2005 .

19 Abu Mus'ab al-Zarqawi, "Announcement of Good News Jama'at al-Tawhid Joins, Flocks under the Banner of alQa'ida" (arabisk), datert 17. oktober 2004, distribuert av Clobal Islamic Media Front, lasted ned 27. november 2004.

20 Se for eksempel "Letter from al-Zawahiri to al-Zarqawi", signert av Abu Muhammad, datert 9. juli 2005, engelsk og arabisk utgave, publisert av the Office of the Director of National Intelligence og "Letter Exposes New Leader in alQa'ida High Command”, Combatting Terrorism Center, 25. september 2006.
21 Se for eksempel Bergen, Peter and Paul Cruickshank: "Al Oaeda in Iraq: Self-Fulfilling Prophecy", Mother Jones, 18. oktober 2007, s.2-3 og Fishman, Brian: "After Zarqawi: The Dilemmas and Future of Al Qaeda in Iraq," The Washington Quarterly, vol 29, nr 4, 2006, s. 19-32.

22 Anonymous: "On the Ground from Syria to Iraq," i Bombers, Bank Accounts, \& Bleedout: al-Qa'ida's Road in and out of Iraq, 81-97 red. Brian Fishman. West Point: Combatting Terrorism Center, 2008 og Felter, Joseph og Brian Fishman: "AlQa'idas Foreign Fighters in Iraq: A First Look at the Sinjar Records," Combatting Terrorism Center Harmony Project, desember 2007 og Denselow, James: "Mosul, the Jazira Region and the Syrian-Iraqi Borderlands," i An Iraq of Its Regions - Cornerstones of a Federal Democracy? red. Reidar Visser and Gareth Stansfield, London: Hurst, 2007, s.100-107.

23 Mellom april 2003 og februar 2010 var det over 100 oo amerikanske militære styrker i Irak. For en god oversikt over antall amerikanske styrker i Irak se O'Hanlon, Michael E. og Ian Livingston: "Iraq Index- Tracking Variables of Reconstruction \& Security in Post-Saddam Iraq", Brookings Institutions, 31. januar 2011 og McLean, Alan og Archie Tse, "American Forces in Afghanistan and Iraq," New York Times, 22. juni 2011.

24 Malkasian, Carter: "A Thin Blue Line in the Sand," Democracy, nr. 5, 2007, s. 48-58.

25 A.McCary, John: "The Anbar Awakening: An Alliance of Incentives", The Washington Quarterly, vol. 32, nr. 1 , 2009, s.43-59 og Long, Austin: "The Anbar Awakening", Survival, vol. 50, nr. 2, 2008, s.67-94.

26 For mer om denne endringen se Truls Hallberg Tønnessen, "Motstand og politikk i Irak," Babylon, vol.8, nr.1, 2010, s. 20-31.

27 “Al-Qa'ida in Iraq Situation Report," Combatting Terrorism Center's Harmony Program, "Advarsel til troens folk (Ahl al-Iman) om det amerikanske bedrag" (på arabisk) signert Tanzim Qa'idat al-Jihad fi Bilad al-Rafidayn, postet 28. februar 2005 på Yahoo! Croup TJN groups. yahoo.com/group/TJN/ av meshawir_azdi og "Vårt standpunkt angående forhandlinger med jødene og korsfarerne" (arabisk) datert 26. juni 2005, signert av Abu Maysarah al-Iraqi på vegne av AQI, postet på Shabakat alAkhbar al-'Alamiyya, www.bayanat.info lastet ned 2. august 2005 .

28 Se for eksempel "Islamic State of Iraq Gives Priority to Targeting Sunnis Who Turned Against State," Jihadist Websites -- OSC Summary, 6. september 2007 via FBIS.

29 Hafez, Mohammed M. "al-Q2a'ida Losing Ground in Iraq", CTC Sentinel, vol. 1, nr 1, 2007, Kilcullen, David J: "Field Notes of Iraq's Tribal Revolt against al-Qa'ida”, CTC Sentinel, vol. 1, nr 11, 2008, s.1-5 og Khalil, Lydia: "Diyala Residents Confront al-Qaeda and the Islamic State of Iraq," Terrorism Focus, vol. 4, nr. 17, juni 2007.

30 Se for eksempel "Al-Oaeda Near Defeat in Iraq, on Defensive Clobally: CIA Chief" AFP, 30. mai 2008, Ricks, Thomas E og Karen DeYoung: "Al-Qaeda In Iraq Reported Crippled," Washington Post, 15. oktober 2007 og Katzman, Kenneth, "Al Oaeda in Iraq: Assessment and Outside Links" CRS Report for Congress, RL32217, 15. august 2008, S.15.

31 For detaljer se for eksempel Benraad, Myriam: "Iraq's Enduring al-Qaeda Challenge," Policywatch 1604, 18. november 2009, Washington Institute for Near East Policy og Fishman, Brian: "Redefining the Islamic State-The Fall and Rise of al-Qaeda in Iraq," New America Foundation, August 2011. 
32 Marr, Phebe: The Modern History of Iraq. Boulder: Westview Press, 2012, s.331-336.

33 I 2009 var Irak rangert som det 176 mest korrupte av 180 land, i 2010175 av 187, i 2011175 av 182, 169 av 176 land i 2012 og i $2013 \mathrm{nr} 171$ av 175 land. "2013 corruption perceptions index”, Transparency International, cpi.transparency.org /cpi2013/.

34 "Failing Oversight: Iraq's Unchecked Government", International Crisis Group, Middle East Report Nr 113, 26. september 2011 og Ottaway, Marina and Danial Anas Kaysi: "Iraq: Protest, Democracy and Autocracy," Carnegie, 28. mars 2011.

35 Se for eksempel Sullivan, Marissa: "Maliki's Authoritarian Regime," Institute for the Study of War, Middle East Security Report 10, april 2013 og "Days of Rage - Protest and Repression in Iraq," Amnesty International, 2011

36 Crane, Keith et.al: "Living Conditions in Anbar Province in June 2008”, RAND National Defense Research Institute, 2009 .

37 Bassem, Wassim: "Money, power draw young Iraqis to IS," al-Monitor, 12. august 2014.

38 Benraad, Myriam: “Assessing AQI's Resilience after April's Leadership Decapitations," CTC Sentinel, vol. 3, nr. 6, 2010, og al-Jabouri, Najim Abdel og Sterling Jensen: "The Iraqi and AQI Roles in The Sunni Awakening," PRISM, vol. 2, nr. 1, 2010.

39 Benraad, Myriam: “Assessing AOI's Resilience after April's Leadership Decapitations," CTC Sentinel, vol. 3, nr. 6, 2010, s.4-8

40 "Abu Bakr al-Baghdadi - a Short Biography of the ISIS Sheikh," pietervanostaeyen.wordpress.com, 15. juli 2013 http://pietervanostaeyen.wordpress.com/2013/o7/15/abubakr-al-baghdadi-a-short-biography-of-the-isis-sheikh/

41 Se for eksempel "Exclusive: Top ISIS leaders revealed," alArabiya, 13. februar 2014.

42 Myriam, Benraad: "Prisons in Iraq: A New Ceneration of Jihadists?," CTC Sentinel, vol. 2, nr. 12, 2009, s.16-18, Ami Angell og Rohan Gunaratna: Terrorist Rehabilitation: The U.S. Experience in Iraq. Boca Raton: CRC Press, 2011. Om overgrep i amerikanske og irakiske fengsler i Irak se for eksempel "The New Iraq? Torture and Ill-treatment of Detainees in Iraqi custody," Human Rights Watch, 25. januar 2005 og "Getting Away with Torture? Command Responsibility for the U.S. Abuse of Detainees," Human Rights Watch, 24. april 2005 .

43 "Iraq's Secular Opposition: The Rise and Decline of alIraqiya," International Crisis Group, Middle East Report 127, 31. juli 2012 og Sowell, Kirk H:, "Iraq's Second Insurgency”, i Current Trends in Islamist Ideology, vol.17, august 2014, s.39-69.

44 For mer om Naqshbandi-hæren se Knights, Michael: "The JRTN Movement and Iraq's Next Insurgency,” CTC Sentinel, vol. 4, nr. 7, juli 2011.

45 For mer bakgrunn om denne protestbevegelsen se for eksempel "Make or Break: Iraq's Sunnis and the State", International Crisis Group, Middle East Report nr. 144, august 2013, Stephen Wicken: "Iraq's Sunnis in Crisis", Institute for the Study of War, mai 2013 og og Sowell, Kirk H:, "Iraq's Second Insurgency", i Current Trends in Islamist Ideology, vol. 17, august 2014, s.39-69.

46 "UN Casualty Figures for December, 2013 deadliest since 2008 in Iraq", United Nations, Iraq.
47 For litteratur om ISIS' rolle i konflikten i Syria se for eksempel al-Tamimi, Aymenn Jawad: "The Dawn of the Islamic State of Iraq and ash-Sham," Current Trends in Islamist Ideology, vol. 16, 2014, s.5-15, Zelin, Aaron Y: “AlQaeda in Syria: A Closer Look at ISIS (Part I)", Policywath 2137, The Washington Institute, 10. september 2013 og Zelin, Aaron Y: "Al-Qaeda in Syria: A Closer Look at ISIS (Part II), Policywath 2138, The Washington Institute, 11. september 2013 .

48 For mer om det kompliserte forholdet mellom ISIS og Nusrafronten/al-Qaida se for eksempel Zelin, Aron: "The War between ISIS and al-Qaeda for Supremacy of the Global Jihadist Movement", The Washington Institute for Near East Policy, juni 2014.

49 Se for eksempel Mortada, Radwan: "Al-Qaeda(s) in Syria: From Foundation to Fracture,”al-Akhbar, 3. juni 2014.

50 Sly, Liz: "Al-Qaeda expands in Syria via Islamic State", the Washington Post, 13. august 2013,

51 al-Tamimi, Aymenn Jawad: "The Syrian rebel groups pulling in foreign fighters", BBC, 24. desember 2013.

52 Lund, Aron: "Pushing Back Against the Islamic State of Iraq and the Levant: The Path to Conflict", Carnegie, 6 January, Barnard, Anne: "Syria Rebels Turn Against Most Radical Group Tied to Al Qaeda”, New York Times, 12. januar 2014 og Yassin-Kassab, Robin. "The rise and fall of ISIL in Syria”, al-Jazeera, 19. januar 2014,

53 Sowell, 59-61.

54 "Iraq: Falluja's Faustian Bargain", International Crisis Group, Middle East Report Nr 150, 28. april 2014 og Sowell, Kirk H:, "Iraq's Second Insurgency", i Current Trends in Islamist Ideology, vol.17, august 2014, s.39-69.

55 For en oversikt se Heras, Nicholas A: "The Tribal Component of Iraq's Sunni Rebellion: The General Military Council for Iraqi Revolutionaries Publication", Terrorism Monitor, vol. 12, nr 13, 26. juni 2014 og Ismaeel, Bashdar Pusho, "A Marriage of Convenience: The Many Faces of Iraq's Sunni Insurgency," Terrorism Monitor, Vol. 12, nr 15, 25. juli 2014.

56 "Inside Mosul: Why Iraqis are Celebrating Islamic Extremists' Takeover of their City," Niqash, 12. juni 2014, Ali, Abdallah Suleiman:, "ISIS prefers allegiance, not allies, in Iraq," al-Monitor, 17. juni 2014 og Fishman, Brian: “ISIS's Secret Allies," The Daily Beast, 13. juni 2014.

57 Abbas, Mushreq "Iraq's 'Sunni' rebellion shows splits between ISIS, others," al-Monitor, 24. juni 2014 og "Iraq crisis: Isis allies 'turn on jihadists' as 17 killed in clashes near Kirkuk," 21. juni 2014. 